\title{
Revision of Threatened Butterfly Species in Hungary (Lepidoptera: Rhopalocera)
}

\author{
Peter Gergely \& Tamás Hudák
}

Citation. Gergely P. \& Hudák T. 2021: Revision of Threatened Butterfly Species in Hungary (Lepidoptera: Rhopalocera). Lepidopterologica Hungarica 17(1): 27-39. DOI: 10.24386/LepHung.2021.17.1.27

\begin{abstract}
The authors revise and update the threat and conservation status of butterflies in Hungary as originally categorised in the Red Data Book (1999). The number of extinct and endangered species both increased during this period.
\end{abstract}

Keywords. Hungary, butterfly, threat, conservation status

Authors' address.

Peter Gergely | 2014 Csobánka, Hegyalja lépcső 4. | Hungary | E-mail: pgergely@alexmed.hu;

Tamás Hudák |1117 Budapest, Hamzsabégi út 13. | Hungary | E-mail: thomashudak1@yahoo.com

\section{Introduction}

The Red Data Book (van Swaay \& Warren 1999) provided an up-to-date review of the threat and conservation status of all 576 butterfly species known to occur in Europe. It listed 6 extinct and 28 Threatened (2 Endangered, 8 Vulnerable and 18 Rare) butterfly species in Hungary (Table 1). The subsequent European Red List of Butterflies (van Swaay et al. 2010) contains only cumulative, European and European Union (EU27) data.

Not unexpectedly, the current threat status of butterflies has worsened since then. A number of endangered species have become extinct, and some rare species deemed to be to be vulnerable or endangered. Even some species with former 'Not Threatened' status have become extinct or threatened. This phenomenon is due to complex environmental impacts, destruction and/or fragmentation of habitats and climatic changes.

\section{Materials and Methods}

We have revised the current status of the listed 28 threatened butterflies and added 16 more species, previously with Not Threatened status. Only one species has been deleted from the former list.

The status was estimated according to the present abundance and the trend in distribution in the last 25 years, as suggested by van Swaay \& Warren (1999):

Present abundance is regarded as the percentage of the total number of investigated grid squares where the species is reported in the past 25 years. It is divided into 5 classes: $<1 \%, 1-5 \%, 5-15 \%,>15 \%$ and unknown.

The trend is the change in species distribution over the last 25 years, in fact it is the comparison of the abundance about 25 years ago with the present abundance. It is also divided into different classes: extinct, $75-100 \%, 50-75 \%, 25-50 \%, 15-25 \%$, more or less stable, $125-200 \%,>200 \%$, strong fluctuations, unknown.

Distribution and occurrence data were obtained by our own observations and those available at the web: https://lepketerkep.termeszet.org/alienSpacePortal.al, https:// lepkeszet.hu/ and https://www.izeltlabuak.hu/; https://hu-hu.facebook.com. Current 
distribution data in publications (Sáfián et al., 2008; Ábrahám et al., 2009; Sáfián 2011; Gór 2018; Hudák 2018) and books (Ábrahám 2012; Haraszthy \& Sáfián 2016; Gergely et al., 2018) were also included.

The threat status was calculated according to the adapted International Union for Conservation of Nature (IUCN) criteria: Critically Endangered (CR), Endangered (EN), Vulnerable (VU), as used by van Swaay \& Warren (1991) (Appendix ) and according to the 2001 IUCN Red List categories and criteria (IUCN 2012).

The IUCN 2001 uses five criteria to assess the extinction risk (CR, EN, VU) of species, in brief:

(A) a past, present and/or projected population reduction measured over 10 years or 3 generations, whichever is longer; since all European butterflies have a generation time of maximum 2 years;

(B) geographic range size in combination with fragmentation, population decline or fluctuations;

(C) small population size in combination with decline or fluctuations;

(D) very small distribution range or restricted population size;

(E) a quantitative analysis of extinction probability.

Species are assigned a threat category when satisfying any one of the criteria A-E.

A taxon is EXTINCT (EX) when there is no reasonable doubt that the last individual has died. A taxon is presumed EX when exhaustive surveys in known and/or expected habitat, at appropriate times (diurnal, seasonal, annual), throughout its historic range have failed to record an individual. Surveys should be over a time frame appropriate to the taxon's life cycle and life form.

A taxon is CRITICALLY ENDANGERED (CR) when the best available evidence indicates that it meets any of the criteria A to E for CR, and it is therefore considered to be facing an extremely high risk of extinction in the wild.

A taxon is ENDANGERED (EN) when the best available evidence indicates that it meets any of the criteria A to E for EN, and it is therefore considered to be facing a very high risk of extinction in the wild.

A taxon is VULNERABLE (VU) when the best available evidence indicates that it meets any of the criteria A to E for VU, and it is therefore considered to be facing a high risk of extinction in the wild.

The 'Rare' category has been replaced by Near Threatened (NT). A taxon which has been categorized as "Near Threatened" (NT) when it has been evaluated against the criteria but does not qualify for Critically Endangered, Endangered or Vulnerable now, but is close to qualifying for or is likely to do so for a threatened category in the near future (IUCN, 2012).

Species that do not qualify as threatened (CR, EN, VU) or NT are categorised as Least Concern (LC). These species are either widespread and occur in several parts of the country or locally abundant and no significant decrease has been observed in the past ten years.

\section{Results}

\section{Extinct (EX) species}

Some of the listed species has been extinct for at least 100 years and some are doubtful residents: vagrants, or specimens of uncertain origin.

Pyrgus sidae (Esper, 1784) - its former presence in Hungary is doubtful (Varga 2010).

Lycaena helle ([Denis \& Schiffermüller], 1775) - definitely extinct.

Lycaena ottomana (Lefébvre, 1830) - its former existence is dubious. The origin of the voucher specimen is doubtful (Varga 2010). 
Polyommatus ripartii (Freyer, 1830) - its former existence is dubious (Varga 2010).

Melanargia russiae (Esper, 1783) - definitely extinct.

Coenonympha tullia (Müller, 1764) - definitely extinct.

\section{Endangered (EN) species}

Coenonympha oedippus (Fabricius, 1787) - stable populations, in particular in Hanság and Kiskunság (Örvössy et al., 2010). Status: EN.

Polyommatus damon ([Denis \& Schiffermüller], 1775) - definitely extinct, last specimens seen in 2014. Status: EX.

Vulnerable (VU) species

Carcharodus lavatherae (Esper, 1783) - possibly extinct, last specimens found more than 7 decades ago (Bálint et al., 2006). Status: EX.

Leptidea morsei major (Lorkovic, 1927) - currently observed only at very few places (Aggtelek Karst). Probably near to extinction. Status: CR.

Pieris mannii (Mayer, 1851) - probably extinct. Definitely absent in Hór-valley (Bükk Mountains) where its most abundant population existed. Current sightings require verification. Status: EX.

Colias myrmidone (Esper, 1781) - definitely extinct (Sáfián 2010). Last sightings were reported in 2004 in Örség. Status: EX.

Plebejus idas (Linnaeus, 1761) - occurs at many places but, due to resemblance to other Plebejus species (e.g., $P$. argus and $P$. argyrognomon), it is less conspicuous in the field. Status: VU.

Limenitis populi (Linnaeus, 1758) - possibly near to extinction in a single locality (Aggtelek Karst). Status: CR.

Apatura iris (Linnaeus, 1758) - occurs in many places in the mountainous areas, rare and numbers are declining. Status: VU.

Apatura ilia ([Denis \& Schiffermüller], 1775) - stable, or increasing populations in many riverside habitats. Status: LC.

\section{'Rare' = Near Threatened (NT) species}

Spialia sertorius (Hoffmannsegg, 1804) - one stable population at Fertörákos (Sáfián et al., 2006); its presence is doubtful elsewhere. This is a small, isolated population, although might be connected to other breeding areas in Lower-Austria. Status: CR.

Pieris bryoniae (Hübner, 1805) - while Pieris bryoniae x Pieris napi hybrids are still living around Galya-tető (Mátra), the original Pieris bryoniae marani population is considered extinct (Bálint et al., 2001). Status: EX (referring to non-hybrid specimens).

Pieris ergane (Geyer, 1828) - relatively stable populations in fluctuating numbers are present in Vértes mountains, Southern and Eastern Bakony. Status: VU.

Colias chrysotheme (Esper, 1781) - relatively stable populations in fluctuating numbers are present in Southern and Eastern Bakony, Mezöföld, Vértes, Gerecse, Pilis, Buda Mountains and Kiskunság. Status: VU.

Cupido osiris (Meigen, 1829) - relatively stable populations in a few places in the Northern mountainous areas. Status: VU.

Jolana iolas (Ochsenheimer, 1816) - Disappeared from many biotopes in the Balaton Highlands. Declining in all its former areas in Southern Hungary (Mecsek Mountains, Villány Hills). Near to extinction. Status: CR.

Maculinea [Phengaris] arion (Linnaeus, 1758) - relatively stable populations in some fragmented habitats, but these areas are shrinking. Status: VU. 
Maculinea [Phengaris] nausithous (Bergsträsser, 1779) - Due to shrinking of bogs, wet meadows, some its former western areas are diminished. However there has been an eastward expansion recently. Most common in Western Transdanubia, but locally it can be found everywhere in the northwest. Status: NT.

Plebejus sephirus (Frivaldszky, 1835) - although its areas have decreased during the past 100 years, current populations seem stable. Status: VU.

Aricia eumedon (Esper, 1780) - very local, threatened due to shrinking of bogs and wet meadows, but relatively stable populations are present in some parts of the Northern mountainous areas, e.g., Tarna-hills, Bükk, Aggtelek Karst. Status: VU.

Aricia artaxerxes (Fabricius, 1793) - very local, but in its biotopes (Bükk, Aggtelek Karst) the populations seem stable. Status: NT.

Polyommatus admetus (Esper, 1783) - similarly, local in the northeast; some populations (e.g.Naszály) have disappeared. Status: VU.

Argynnis laodice Pallas, 1771) - localized to the North-eastern part of Hungary (Tarnahills, Bükk, Zemplén, Aggtelek Karst). Populations seem stable, but its areas are shrinking. Status: VU.

Euphydryas aurinia (Rottemburg, 1775) - while original wet biotopes are shrinking, this species successfully colonized less disturbed ones. Now its populations are stable, in particular in dry calcareous grasslands (Bakony, Vértes, Balaton-highlands, Western Transdanubia). Status: NT.

Euphydryas maturna (Linnaeus, 1758) - stable populations at many places. Status: NT.

Apatura metis (Freyer, 1829) - stable populations at some riverside areas, in particular near the Danube and Dráva. Status: NT.

Melitaea diamina (Lang, 1789) - locally present in many places, but due to resemblance to other Melitaea species, it is less conspicuous in the field and therefore, its sightings are questionable. Status: NT.

Chazara briseis (Linnaeus, 1764) - relatively stable populations in decreasing numbers with fluctuations, only in Southern and Eastern Bakony. Disappeared from several former habitats. Status: EN.

\section{'Not threatened' = Least Concern (LC) species}

These species were listed as 'not threatened' in the Red Data Book 1999, i.e. Least Concern according to new nomenclature. However, their IUCN status has changed, in some instances dramatically, during the past decades in Hungary.

\section{A/ Extinct}

Nymphalis vau-album ([Denis \& Schiffermüller], 1775) - was always very rare, in the last thirty years it has been observed only once in the southernmost part of Transdanubia (2005, Szársomlyó). It cannot establish stable populations in Hungary. Vagrant specimens, however, may occur at any time. Its closest breeding areas are in Serbia (Gascoigne-Pees et al., 2014) and Romania (Rákosy 2013).

Erebia ligea (Linnaeus, 1758) - extinct or near to extinction. No records from recent years; formerly reported from the Zemplén Mountains. Status: EX.

B/ Critically Endangered

Hyponephele lycaon (Kühn, 1774) - probably extinct. Recent sightings require verification. Status: CR.

Hyponephele lupina (Costa, 1836) - breeding areas are continuously shrinking. Fragmented populations with decreasing numbers exist in the Southern sandy plains. Status: CR.

Erebia aethiops (Esper, 1777) - due to habitat destruction, populations have dramatically decreased or may have already disappeared in Western Transdanubia. Currently occurs in fragmented habitats only in Zemplén Mountains and Aggte- 


\section{C/ Endangered}

lek Karst. Status: CR.

Pyrgus serratulae (Rambur, 1839) - rare and local. Small and less conspicuous, but similar to some common skippers, and therefore records may easily be missed. Status: EN.

Pyrgus alveus (Hübner, 1803) - very rare and local. Its current occurrence is not known. Status: EN.

Lycaena hippothoё (Linnaeus, 1776) - in steep decline; present only in the West and in the Northern Mountains, extinct from most of Transdanubia. Status: EN.

Limenitis reducta (Staudinger 1901) - currently present only in a few localities in southern Transdanubia. Most of its habitats are not protected. Status: EN.

Argynnis niobe (Linnaeus, 1758) - dramatically decreased in number, and present in only a few places in the mountains and in the Kiskunság plain. Status: EN.

Melitaea ornata kovacsi (Varga, 1967) - very local, currently observed only in a few places. Status. EN.

Lopinga achine (Scopoli, 1763) - disappeared from many former habitats. Now still very local in North-eastern and South-western Hungary in wet, partly open forests. Status: EN.

D/ Vulnerable

Satyrium w-album (Knoch, 1782) - has become increasingly rare in the past decade. Status: VU.

Limenitis camilla (Linnaeus, 1764) - has disappeared from many regions, present only in some mountainous areas. Status: VU.

Aglais urticae (Linnaeus, 1758) - this once common species has suffered severe decline. Now occurs only in cooler biotopes: mountain tops or cooler valleys. Status: VU.

Nymphalis antiopa (Linnaeus, 1758) - dramatically decreased in number. Currently occurs only in the cooler mountainous areas. Status: VU.

Hipparchia statilinus (Hufnagel, 1766) - breeding areas are continously shrinking. Currently occurs only in sandy areas east of the Danube and in Transdanubia there is only one small population. Status: VU.

\section{E/ Near Threatened}

Thymelicus acteon (Rottemburg, 1775) - occurs in scattered areas but rare. Small and less conspicuous, resembles some common skippers, and therefore records may be missed. Status: NT.

Maculinea [Phengaris] alcon ([Denis \& Schiffermüller], 1775) - habitats are shrinking and threatened. Relatively stable, partly isolated populations and it has become highly local. Status: NT.

Maculinea [Phengaris] teleius (Bergsträsser, 1779) - habitats are shrinking and threatened. Local but in its habitats it can be common. Status: NT.

Polyommatus amandus (Schneider, 1792) - occurs in some mountainous places and on the Bereg Plain. Its populations are small and fluctuating. Usually rare. Status: NT.

Neptis rivularis (Scopoli, 1763) - occurs locally in decreased number, usually around planted Spiraea bushes in suburban areas. Status: NT.

Brenthis ino (Rottemburg, 1775) - occurs in some mountains and wet areas in decreasing number. Status: NT.

Nymphalis xanthomelas ([Denis \& Schiffermüller], 1775) - considered extinct for more than 20 years, then reappeared (Sáfián et al., 2008) and currently has stable populations mainly in the north and northeast. Status: NT.

Pyronia tithonus (Linnaeus, 1771) - occurs locally in the southwest. In its habitats it can be common. Status: NT. 


\section{Species with doubtful presence in Hungary}

These non-resident species are not included in the Red Data Book (van Swaay \& Warren 1999), but they are listed in some of the textbooks:

Muschampia cribrellum (Eversmann, 1841) - probably never existed in Hungary (Varga 2010). Its nearest breeding area is in the Transylvanian Plain, Romania (Rákosy 2013).

Parnassius apollo (Linnaeus, 1758) - currently absent; its former habitats (Köszeg, Bükk) are debated (Varga 2010).

Colias palaeno (Linnaeus, 1761) - its inclusion is based on a vagrant specimen (Varga 2010).

Anthocaris gruneri (Herrich-Schäffer, 1850) - its inclusion is based on an accidentally introduced specimen (Varga, 2010).

Polyommatus escheri (Hübner, 1823) - although two specimens were collected in Buda in 1911, and one of them is still in the collection of Hungarian Natural History Museum (Gozmány 1968), its former presence has continuously been debated (Bálint, 1985).

Boloria titania (Esper, 1793) - currently absent, its former presence is unlikely and uncertain (Gozmány 1968).

Coenonympha hero (Linnaeus, 1761) - currently absent; its former existence is unlikely and debated (Gozmány 1968).

Lasiommata petropolitana (Fabricius, 1787) - occurrence considered unlikely, but cannot be excluded, therefore requires verification (Varga 2010).

Hipparchia alcyone ([Denis \& Schiffermüller], 1775) - previous occurrence considered possible, but verification required (Varga 2010).

Danaus plexippus (Linnaeus, 1758) - accidentally introduced specimens have been observed (Dietzel 1997; Gergely et al., 2018).

The updated list is shown in Table 2. Current IUCN Red List Category in Europe (van Swaay et al., 2010) is shown in brackets.

There are a few species listed in Near Threatened category in Europe (van Swaay et $a l ., 2010)$ that are currently placed in Least Concern category in Hungary (Table 3).

\section{Conclusions}

There are 13 extinct species. Seven species: Carcharodus lavatherae, Polyommatus damon, Colias myrmidone, Pieris mannii, Pieris bryoniae, Nymphalis vau-album and Erebia ligea have become extinct in the past few decades. The last specimens of Polyommatus damon were observed in 2014! While Pieris bryoniae x napi hybrids still occur in one habitat, the original Pieris bryoniae marani population can be considered extinct (Bálint \& Ilonczai 2001). Four species (Leptidea morsei, Jolana iolas, Limenitis populi and Hyponephele lycaon) are either already extinct or on the verge of extinction; their status was categorised as critically endangered (CR). Three more critically endangered species, Spialia sertorius, Hyponephele lupine and Erebia aethiops, are also near to extinction. Nine species were categorized as Endangered, 15 as Vulnerable and 14 Near Threatened. Only one species, Apaturia ilia has been omitted (classified as LC). This species formerly was classified as Vulnerable but currently thrives in all former habitats, as well as having populated many new habitats.

The sum of currently threatened species is 45. Extinct species (13) are not included. There is a marked discrepancy between the list of threatened species in Hungary and those listed in IUCN Red List of European butterflies (van Swaay et al., 2010). Some species, including Pieris bryoniae and Aglais urticae, have either disappeared from 
Hungary or have dramatically decreased in number, still thrive in cooler and/or mountainous habitats.

We agree entirely with the conclusions of the 1999 Red Data Book that stated: “... many European butterflies are continuing to decline at an alarming rate, and we can only conclude that existing measures are inadequate. A major new initiative for conserving Europe's butterflies must therefore be developed urgently if we are to stem their declines and ensure they are conserved far more effectively in the future. We hope this review will provide the impetus for this to happen without any further delay." (van Swaay \& Warren 1999).

Now, after almost 25 years, we have to admit that the dramatic decline of butterflies and habitat destruction still continues. Much more rigorous measures need to be taken to conserve our biodiversity. Meanwhile, continuous monitoring of these threatened species is required.

Table 1. List of Threatened Butterfly Species in Hungary (after van Swaay \& Warren 1999)

\section{Extinct}

Pyrgus sidae (Esper, 1784)

Lycaena helle ([Denis \& Schiffermüller], 1775)

Lycaena ottomana (Lefébvre, 1830)

Polyommatus ripartii (Freyer, 1830)

Melanargia russiae (Esper, 1783)

Coenonympha tullia (Müller, 1764)

\section{Endangered}

Coenonympha oedippus (Fabricius, 1787)

Polyommatus damon ([Denis \& Schiffermüller], 1775)

\section{Vulnerable species}

Carcharodus lavatherae (Esper, 1783)

Leptidea morsei major (Lorkovic, 1927)

Pieris mannii (Mayer, 1851)

Colias mymidone (Esper, 1781)

Plebejus idas (Linnaeus, 1761)

Limenitis populi (Linnaeus, 1758)

Apatura iris (Linnaeus, 1758)

Apatura ilia ([Denis \& Schiffermüller], 1775)

\section{Rare}

Spialia sertorius (Hoffmannsegg, 1804)

Pieris bryoniae (Hübner, 1805)

Pieris ergane (Geyer, 1828)

Colias chrysotheme (Esper, 1781)

Cupido osiris (Meigen, 1829)

Jolana iolas (Ochsenheimer, 1816)

Maculinea [Phengaris] arion (Linnaeus, 1758)

Maculinea [Phengaris] nausithous (Bergsträsser, 1779)

Plebejus sephyrus (Frivaldszky, 1835) *

Aricia eumedon (Esper, 1780)

Aricia artaxerxes (Fabricius, 1793) 
Polyommatus admetus (Esper, 1783)

Argynnis laodice (Pallas, 1771)

Euphydryas aurinia (Rottemburg, 1775)

Euphydryas maturna (Linnaeus, 1758)

Apatura metis (Freyer, 1829)

Melitaea diamina (Lang, 1789)

Chazara briseis (Linnaeus, 1764)

* mentioned as Plebejus pylaon- the original list used the latest comprehensive list of butterflies in the whole of Europe: Karsholt O. \& Razowski J. 1996. The Lepidoptera of Europe. A Distributional Checklist. - Apollo Books, Stenstrup, Denmark.

Table 2. Current List of Threatened Butterfly Species in Hungary. In Brackets: Current IUCN Red List Category - Europe (according to van Swaay et al., 2010)

\section{Extinct species}

Carcharodus lavatherae (Esper, 1780) (NT)

Pyrgus sidae (Esper, 1784) (LC)

Pieris mannii (Mayer, 1851)(LC)

Pieris bryoniae (Hübner, 1805) (LC)

Colias mymidone (Esper, 1781) (EN)

Lycaena helle ([Denis \& Schiffermüller], 1775) (EN)

Lycaena ottomana (Lefébvre, 1830) (LC)

Polyommatus ripartii (Freyer, 1830) (LC)

Polyommatus damon ([Denis \& Schiffermüller], 1775) (NT)

Nymphalis vau-album ([Denis \& Schiffermüller], 1775) (LC)

Melanargia russiae (Esper, 1783) (LC)

Coenonympha tullia (Müller, 1764) (VU)

Erebia ligea (Linnaeus, 1758) (LC)

\section{Critically Endangered}

Spialia sertorius (Hoffmannsegg, 1804)(LC)

Leptidea morsei major (Lorkovic, 1927) (NT)

Jolana iolas (Ochsenheimer, 1816)(NT)

Limenitis populi (Linnaeus, 1758) (LC)

Hyponephele lycaon (Kühn, 1774) LC)

Hyponephele lupina (Costa, 1836) LC)

Erebia aethiops (Esper, 1777) LC)

\section{Endangered}

Pyrgus serratulae (Rambur, 1839) (LC)

Pyrgus alveus (Hübner, 1803) (LC)

Lycaena hippothoë (Linnaeus, 1776) (LC)

Limenitis reducta (Staudinger 1901) (LC)

Argynnis niobe (Linnaeus, 1758) (LC)

Melitaea ornate kovacsi (Varga, 1967) (DD)*

Coenonymphao edippus (Fabricius, 1787) (EN)

Lopinga achine (Scopoli, 1763) (VU)

Chazara briseis (Linnaeus, 1764) (LC) 


\section{Vulnerable species}

Pieris ergane (Geyer, 1828) (LC)

Colias chrysotheme (Esper, 1781) (VU)

Satyrium w-album (Knoch 1782) (LC)

Cupido osiris (Meigen, 1829) LC)

Plebejus idas (Linnaeus, 1761) (LC)

Maculinea [Phengaris] arion (Linnaeus, 1758) (EN)

Plebejus sephirus (Frivaldszky, 1835) (LC)

Polyommatus admetus (Esper, 1783) (LC)

Aricia eumedon ( Esper, 1780) (LC)

Apatura iris (Linnaeus, 1758) (LC)

Limenitis camilla (Linnaeus, 1764) (LC)

Argynnis laodice (Pallas, 1771) (LC)

Aglais urticae (Linnaeus, 1758) (LC)

Nymphalis antiopa (Linnaeus, 1758) (LC)

Hipparchia statilinus (Hufnagel, 1766) (NT)

\section{Near Threatened}

Thymelicus acteon (Rottemburg, 1775) (NT)

Maculinea [Phengaris] alcon ([Denis \& Schiffermüller], 1775) (LC)

Maculinea [Phengaris] teleius (Bergsträsser, 1779) (VU)

Maculinea [Phengaris] nausithous (Bergsträsser, 1779) (NT)

Aricia artaxerxes (Fabricius, 1793) (LC)

Polyommatus amandus (Schneider, 1792) (LC)

Apatura metis (Freyer, 1829) (LC)

Neptis rivularis (Scopoli, 1763) (LC)

Euphydryas aurinia (Rottemburg, 1775) (LC)

Euphydryas maturna (Linnaeus, 1758) (VU)

Brenthis ino (Rottemburg, 1775) (LC)

Nymphalis xanthomelas ([Denis \& Schiffermüller], 1775) (LC)

Melitaea diamina (Lang, 1789) (LC)

Pyronia tithonus Linnaeus, 1771) (LC)

* DD: Data Deficient

Table 3. Species in Near Threatened Category in Europe (van Swaay et al., 2010). Not Listed in Table 2 for they are in Least Concern Category in Hungary

Carcharodus flocciferus (Zeller, 1847)

Parnassius mnemosyne (Linnaeus, 1758)

Cupido decoloratus (Staudinger, 1886)

Polyommatus dorylas ([Denis \& Schiffermüller],

Pseudophilotes vicrama (Moore, 1865)

Melitaea aurelia (Nickerl, 1850)

Melitaea britomartis (Assmann, 1847)

Hipparchia fagi (Scopoli, 1763) 


\section{Appendix I.}

Categories Used to Establish the Threat Status of Butterflies Compared to the IUCN Criteria (after van Swaay \& Warren 1999)

\section{CRITICALLY ENDANGERED}

A. Population reduction of at least $80 \%$ over the last 10 years.

B. Extent of occurrence less than $100 \mathrm{~km}^{2}$ and two of the following:

1. severely fragmented or known to exist at only a single location;

2. continuing decline;

3 . extreme fluctuations.

C. Population estimates fewer than 250 mature individuals and a strong decrease.

D. Population estimate fewer than 50 individuals.

E. Probability of extinction at least $50 \%$ within 10 years.

\section{ENDANGERED}

A. Population reduction of at least $50 \%$ over the last 10 years.

B. Extent of occurrence less than $5000 \mathrm{~km}^{2}$ and two of the following:

1. severely fragmented or known to exist at no more than five locations;

2. continuing decline;

3. extreme fluctuations.

C. Population estimates fewer than 2500 mature individuals and a decrease.

D. Population estimate fewer than 250 individuals.

E. Probability of extinction at least $20 \%$ within 20 years.

\section{VULNERABLE}

A. Population reduction of at least $20 \%$ over the last 10 years.

B. Extent of occurrence less than $20000 \mathrm{~km}^{2}$ and two of the following:

1. severely fragmented or known to exist at no more than ten locations;

2. continuing decline;

3. extreme fluctuations.

C. Population estimates fewer than 10000 mature individuals and a decrease.

D. Population estimate fewer than 1000 individuals.

E. Probability of extinction at least $10 \%$ within 100 years. 

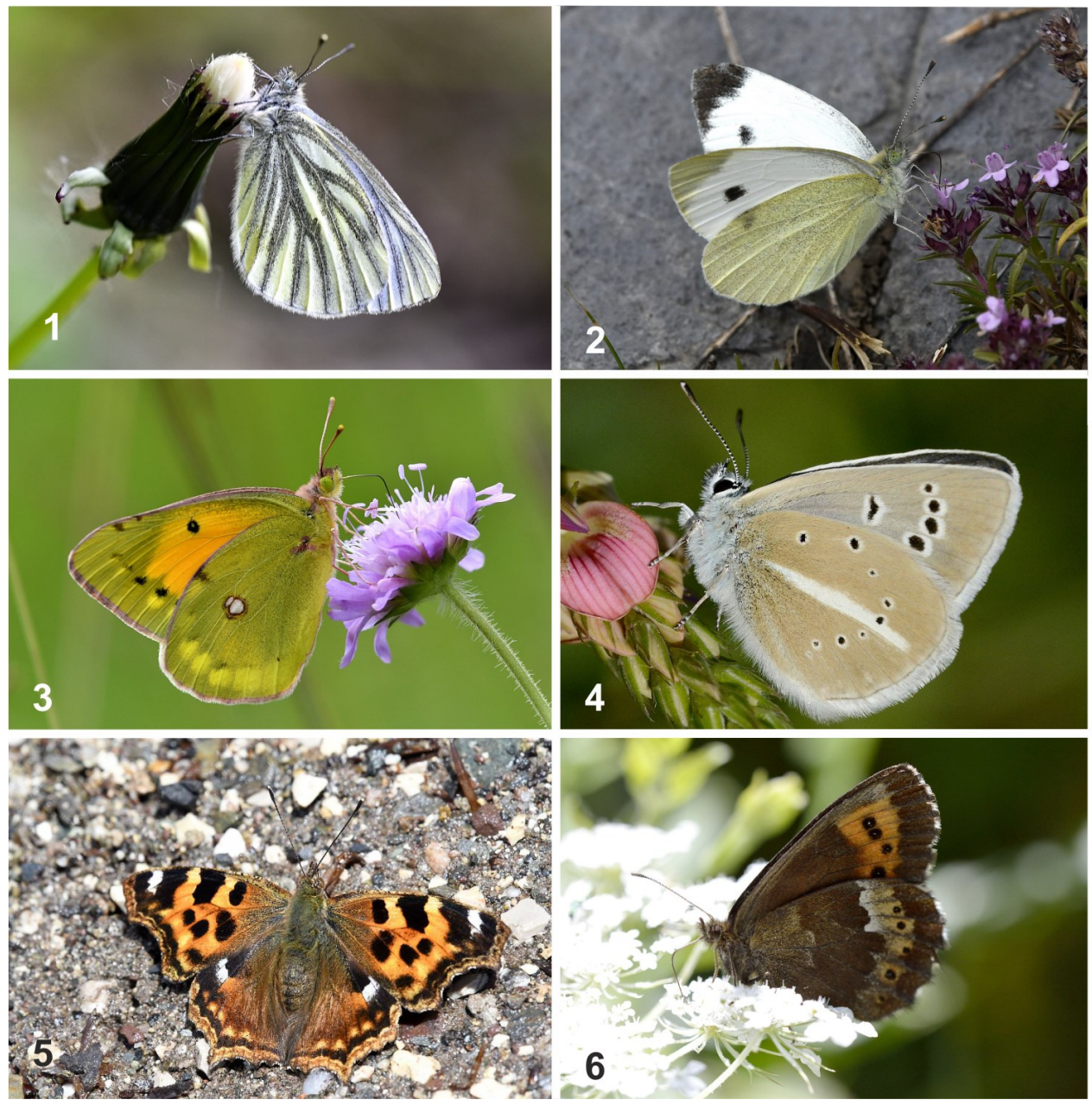

Fig. 1. Pieris bryoniae x napi hybrid (of bryoniae phenotype) - Galya-tető, Mátramountains, Hungary, 30.05.2015.

Fig. 2. Pieris mannii - Theth, Albania, 04.08.2019.

Fig. 3. Colias myrmidone - Gyergyószentmiklós, Romania, 28.07.2017.

Fig. 4. Polyommatus damon - Harang-valley, Budapest, Hungary, 06.07.2014. Perhaps the last Hungarian specimen.

Fig. 5. Nymphalis vau-album - Babin Zub, Serbia, 22.06.2019.

Fig. 6. Erebia ligea - Hohe Wand, Austria, 02.08.2013.

(Note: different scales) 


\section{References}

Ábrahám L. (ed.) 2012: Nappali lepke atlasz - Atlas dnevnih metuljev - Butterfly atlas. Örség, Goricko. - Örségi Nemzeti Park Igazgatóság, 248 p.

Ábrahám L., Uherkovich A. \& Szeőke K. 2009: Survey on the buttrefly and larger moth (Lepidoptera. Macrolepidoptera) fauna of Gyürüfü Biodiversity Days (SW Hungary). - Natura Somogyiensis 13:169-178 [in Hungarian with English abstract].

Bálint Z. 1985: Plebicula escheri Hübner, 1823 in the Carpathian Basin? (Lepidoptera, Lycaenidae). - Nota Lepidopterologica 8: 289-292.

Bálint Z. \& Ilonczai Z. 2001: On the populations of Pieris bryoniae marani Moucha, 1956 (Lepidoptera: Pieridae) of the Bükk Mts, NE Hungary. - Folia Entomologica Hungarica 62: 388-91.

Bálint Zs. 2015: Notes on the Damon Blue, Polyommatus damon ([Denis \& Schiffermüller], 1775) in the year 2014 (Lepidoptera: Lycaenidae). - e-Acta Naturalia Pannonica 8: 143-162 [in Hungarian with English abstract].

Dietzel Gy. 1997: A Bakony nappali lepkéi. - Bakonyi Természettudományi Múzeum, Zirc. p. 174 [in Hungarian with English summary].

Gascoigne-Pees M., Wiskin C., Durić M. \& Trew D. 2014: The lifecycle of Nymphalis vaualbum ([Denis \& Schiffermüller], 1775) in Serbia including new records and a review of its present status in Europe (Lepidoptera: Nymphalidae). - Nachrichten des Entomologischen Vereins Apollo N.F. 35: 77-96.

Gergely P., Gór A., Hudák T., Ilonczai Z. \& Szombathelyi E. 2018: Nappali lepkéink. Határozó terepre és természetfotókhoz. - Kitaibel Kiadó, Biatorbágy, 264 p. [in Hungarian].

Gozmány L. 1968: Nappali lepkék - Diurna. Magyarország Állatvilága - XVI. Akadémiai Kiadó, Budapest, 98 p. [ in Hungarian].

Gór Á. 2018: Lepidoptera survey in Biatorbágy (Hungary) and its surrounding areas. e-Acta Naturalia Pannonica 16: 55-70 [in Hungarian with English abstract].

Haraszthy L. \& Sáfián Sz. (eds.) 2016: Védett állatok elterjedési atlasza Vas, Zala és Somogy megye Natura 2000 területein. 2016. - Somogy Természetvédelmi Szervezet, Somogyfajsz, pp. 64-83 [in Hungarian].

Hudák T. 2018: Investigations on the butterfly fauna of Székesfehérvár (Lepidoptera). - Natura Somogyiensis 31: 113-136 [ in Hungarian with English abstract].

IUCN Red List categories and criteria, version 3.1., second edition. 2012. accessed at: https://www.iucnredlist.org,

Örvössy N., Vozár Á., Kőrösi Á., Batáry P. \& Peregovits L. 2010: Structure and size of a threatened population of the False Ringlet Coenonympha oedippus (Fabricius, 1787) (Lepidoptera: Nymphalidae) in Hungary. - Oedippus 26: 31-7.

Rákosy L. 2013: Fluturiidiurni din Romania. - Mega, Cluj-Napoca, p. 285 [in Romani an].

Sáfián Sz, Hadarics T, Szegedi B. \& Horváth A. 2006: Occurrences of rare butterfly and moth species (Lepidoptera) from a limestone quarry at Fertorrákos. Szélkiáltó12: 28-32 [ in Hungarian with English abstract].

Sáfián Sz., de Jong R. \& Korompai T. 2008: Migration of yellow-legged tortoiseshell Nymphalis xanthomelas (Esper,[1781]) in the Zemplén Mountains (Lepidoptera, Nymphalidae). - Natura Somogyiensis 12: 169-175 [in Hungarian with English abstract].

Sáfián Sz., de Jong R. \& Ilonczai Z. 2008: Geranium Argus - Aricia eumedon (Esper, 1780) from the Bükk Plateau, Bükk Hills. Relict or present day dispersion? - Folia Historico Naturalia Musei Matrensis 32: 15-18 [in Hungarian with English abstract]. 
Sáfián Sz., Szentirmai I., Mesterházy A. \& Horváth B. 2010: The extinction of Danube Clouded Yellow - Colias myrmidone (Esper, 1781) from the Örség National Park and Hungary. - Poster. VIII. Butterfly Conservation Symposium, Reading.

Sáfián Sz. 2011: Butterflies of Kercaszomor (Örség), Western Hungary (Lepidoptera: Papilionoidea and Hesperioidea). - Natura Somogyiensis 19: 251-262 [in Hungarian with English abstract].

van Swaay C. \& Warren M. 1999: Red Data Book of European Butterflies (Rhopalocera). - Convention on the Conservation of European Wildlife and Natural Habitats Nature and Environment, No. 99 Council of Europe Publishing, pp. 1260.

Van Swaay C., Cuttelod A., Collins S., Maes D., López Munguira M., Šašić M., Settele J., Verovnik R., Verstrael T., Warren M., Wiemers M. \& Wynhof, I. 2010: Europe an Red List of Butterflies. - Luxembourg, Publications Office of the European Union pp. 1-47.

Varga Z. (ed). 2010: Magyarország nagylepkéi | Macrolepidoptera of Hungary. - Heterocera Press, Budapest, pp. 121-130.

Verovnik R., Verstrael T., Warren M., Wiemers M. \& Wynhof I. 2010: European Red List of Butterflies. - Luxembourg: Publications Office of the European Union. pp $1-47$. 
